\title{
Effects of y Irradiation Dose on Sensory Acceptability of a Ready-to-Eat Spinach RELISH and Sorghum Porridge Meal
}

\author{
Renatus P. Shilangale \\ Central Veterinary Laboratory, Ministry of Agriculture Water and Forestry, Windhoek, \\ Namibia \\ Email: rpshilangale@yahoo.com
}

Received 8 October 2014; revised 29 October 2014; accepted 15 November 2014

Copyright (C) 2014 by author and Scientific Research Publishing Inc.

This work is licensed under the Creative Commons Attribution International License (CC BY).

http://creativecommons.org/licenses/by/4.0/

(c) () Open Access

\section{Abstract}

To establish the highest irradiation dose, which was still organoleptically acceptable for producing ready-to-eat (RTE) sorghum porridge and spinach morôgo meal if irradiation could be used as a preservation method. Study design: In order to produce a safe RTE meal made of these two meal components, a consumer sensory acceptability test was done on the meal irradiated at different doses of 0, 10, 20 and 30 kGy. Place and Duration of Study: Department of Food Science, University of Pretoria, between January 2000 to December 2000. Methodology: A consumer sensory acceptability test was done on the two meal components irradiated at different doses of $0,10,20$ and 30 kGy. The sensory acceptability test on the appearance, texture, taste, and overall acceptability of the RTE meal components were evaluated. Results: The consumer overall acceptability test results showed that the two components of the meal remained acceptable up to a dose of $10 \mathrm{kGy}$ (p < 0.05). The loss in appearance was observed by the panellists in the two components of the meal where the texture changed with increased irradiation doses $(p<0.05)$. However, irradiation had less effect on the taste of the spinach than on the sorghum porridge $(p<0.05)$. Overall, irradiating up to $10 \mathrm{kGy}$ produced a RTE meal with acceptable sensory qualities.

\section{Keywords}

Ready-to-Eat (RTE) Meal, Irradiation

\section{Introduction}

Sorghum cereal grain has been acknowledged to be one of the most important subsistence grains in most African

How to cite this paper: Shilangale, R.P. (2014) Effects of y Irradiation Dose on Sensory Acceptability of a Ready-to-Eat Spinach RELISH and Sorghum Porridge Meal. Food and Nutrition Sciences, 5, 2105-2114. 
societies especially in the semi-arid areas [1]. In Southern Africa, porridge made from sorghum has traditionally been considered to be the staple diet of many African societies, particularly among the Tswana of Botswana and South Africa [2]. According to Van Eeden and Gerickestudy [3], thick porridge was found to be the most popular traditional food source while wild greens, cooked pumpkin and a mix of spinach, cabbage and turnips were the vegetables used on a regular basis.

In South Africa, about $60 \%$ of the population is concentrated in formal and informal urban areas. Most of these people depend on commercially produced food products. It has been thought that there are significant numbers of people (in urban areas) among the black societies who prefer traditional meals. One example of these meals is spinach (morôgo) or amaranthus based relishes which is consumed with either maize or sorghum porridge. These traditional foods have a short shelf life, are laborious to prepare [4] and are hardly produced commercially [5].

Survival and growth of spores of pathogenic micro-organisms in these traditional foods can be of safety concern especially as most leafy vegetables as well as cereal porridges are low acid foods ( $\mathrm{pH}>4.6)$. The spores of mesophilic anaerobic bacteria germinate and grow readily in low acid foods [6].

Hence, there is a need to try methods or a combination of methods to ensure the safety of these low acid food products. One of the preservation methods could be a food irradiation technique. Food irradiation has received much attention due to its potential effect on the microbiological safety of food. Irradiation has been successfully used to reduce pathogenic bacteria, eliminate parasites, decrease postharvest sprouting, and extend the shelf life of fresh perishable foods [7]. From a microbiological point of view food irradiation has demonstrated that radiation will make food safer and improve its shelf life [8]. However, the potential of irradiation to alter organoleptic characteristics of food may limit its use as a preservation technique of some foods. Therefore, it is important to establish acceptable irradiation dose which does not alter the sensory properties of food when irradiation is used as preservation technique.

The objective of this study was to establish the highest irradiation dose, which was still organoleptically acceptable for producing ready-to-eat (RTE) sorghum porridge and spinach morôgo meal if irradiation could be used as a preservation method.

\section{Material and Methods}

\subsection{Preparation of a RTE Sorghum Porridge and Spinach Relish}

Spinach (morôgo) and sorghum porridge meal samples were prepared at the Department of Food Science, University of Pretoria, Republic of South Africa. Sorghum porridge and spinach based relish meals were prepared following the method adapted from Duodu et al. [4] (Figure 1). Sorghum flour (Super Mabela sorghum flour) was supplied by Nola (Pty) Ltd., Randfontein while spinach (morôgo) leaves were obtained from one of the producers of spinach in the Pretoria area. Tomato onion mix (FARMGIRL Maxim Packers, South Africa), white pepper (Pick ' $n$ Pay's Choice) and salt were purchased from the Pick 'n Pay Supermarket, Hatfield, Pretoria. After preparation, samples were stored at temperatures between $4^{\circ} \mathrm{C}$ and $10^{\circ} \mathrm{C}$ before being taken for irradiation the following day. Samples were irradiation at 0, 10, 20, $30 \mathrm{kGy}$ by the ISO-STER, Isando, Kempton in the Republic of South Africa one day before the sensory evaluation.

\subsection{Sensory Acceptability Test}

To investigate the effect of irradiation on the sensory acceptability of the RTE meal, samples irradiated at 0,10 , 20 and 30 kGy were subjected for a sensory evaluation test. A consumer acceptance test was performed for irradiated spinach relish and sorghum porridge samples. The sensory evaluation was done on the samples the same day they were received from the irradiation plant.

\subsection{Sensory Test Method}

A hedonic rating scale was used to determine the consumer acceptability of the RTE meal. An evaluation form with a 9-point rating scale ranging from "dislike extremely" to "like extremely" was used by participants to assess the acceptability of the sensory quality characteristics (appearance, texture and taste), and the overall acceptability of the RTE meal irradiated at different doses. Except for overall acceptability, meal components were assessed for appearance, texture and taste separately. 


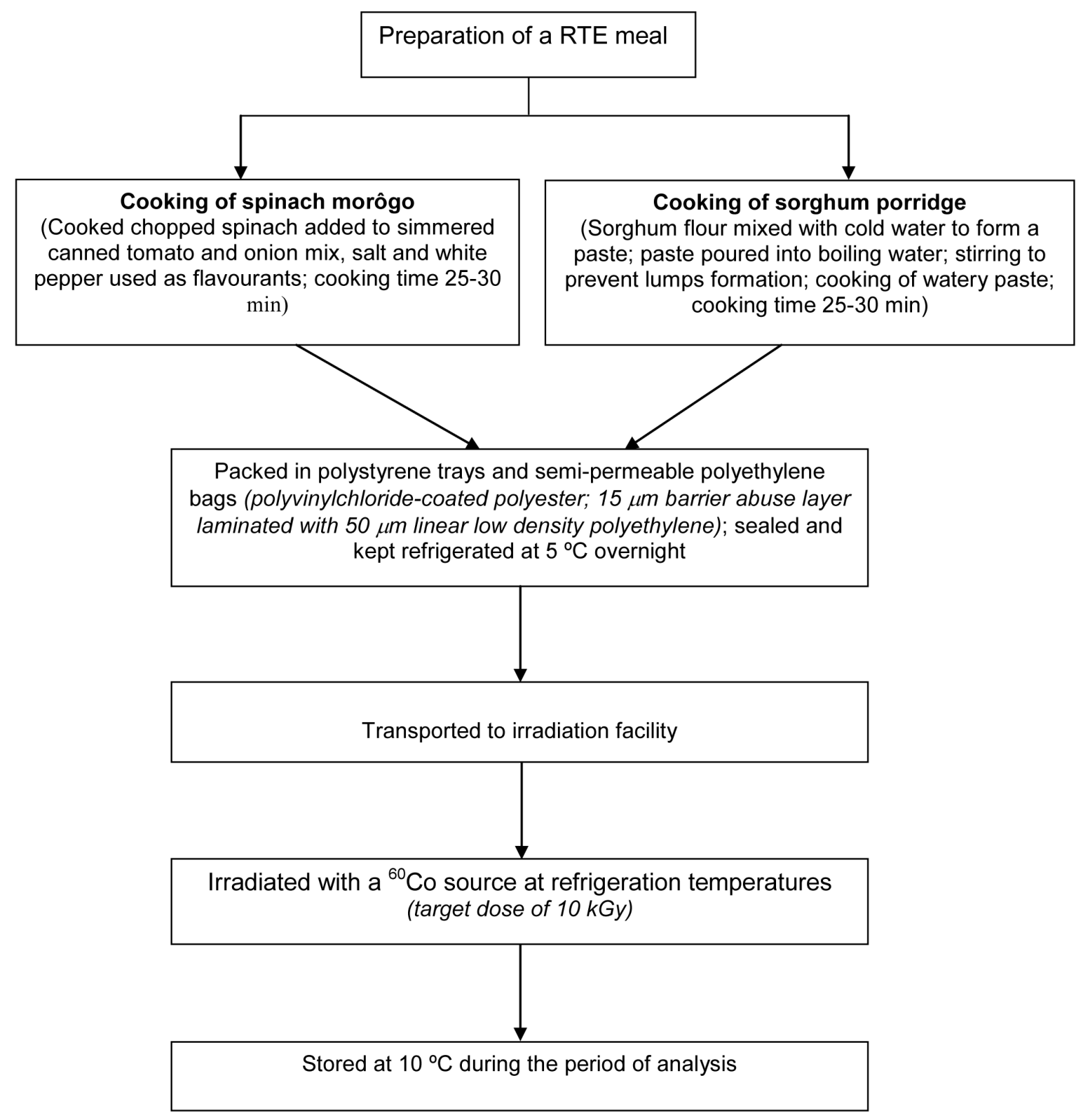

Figure 1. Flow diagram of preparation and processing of the RTE spinach morôgo and sorghum porridge meal.

\subsubsection{Test Panel}

Recruitment of the test panel was carefully done in selecting the 50 test panelists. The group of the test panelists comprised students and personnel from the University of Pretoria. Only individuals that were familiar with, and regularly consumed this type of meal, were chosen.

\subsubsection{Test Location}

The sensory evaluation test was performed in the Home Economics Dining room, at the Department of Home Economics (University of Pretoria). At least 25 participants were accommodated at a time, and they were divided into two groups of which each group had a session to attend. The conditions in the testing room were controlled and participants were supervised during the test session. Individual assessment was followed throughout the test i.e. communication between panellists was not allowed. Daylight conditions were used throughout the testing period. 


\subsubsection{Test Procedure}

Samples (approximately $30 \mathrm{~g}$ sorghum porridge and $25 \mathrm{~g}$ spinach relish) were portioned into ramekins (porcelain containers) and covered with aluminium foil. Samples were then reheated in an AEG oven to an internal temperature of $55^{\circ} \mathrm{C}-60^{\circ} \mathrm{C}$ before being served. Before serving, samples were coded with 3 digit numbers and served in a randomized fashion to minimize bias. Panellists were familiarized with the evaluation forms and left to evaluate samples following the form's description. Explanation of the terms used to describe various characteristics of samples was given to panellists where it was necessary.

\section{Results and Discussion}

\subsection{Results}

Table 1 and Figures 2-8 show the effect of different irradiation doses on the sensory characteristics of the ready-to-eat sorghum porridge and spinach based relish meal. Table 1 shows the mean values of the appearance, texture, and taste of the spinach and sorghum porridge components, and the overall acceptability of the meal; the attributes that were used to describe the sensory characteristics of the two meal components subjected to four different irradiation doses (0, 10, 20 and $30 \mathrm{kGy})$. Figures 2-8 show the distribution of panellists for liking the four different irradiated samples. Comments of panellists are summarized in Table 2 and Table 3.

In general, for the spinach relish component of the meal, there was no significant difference $(p<0.05)$

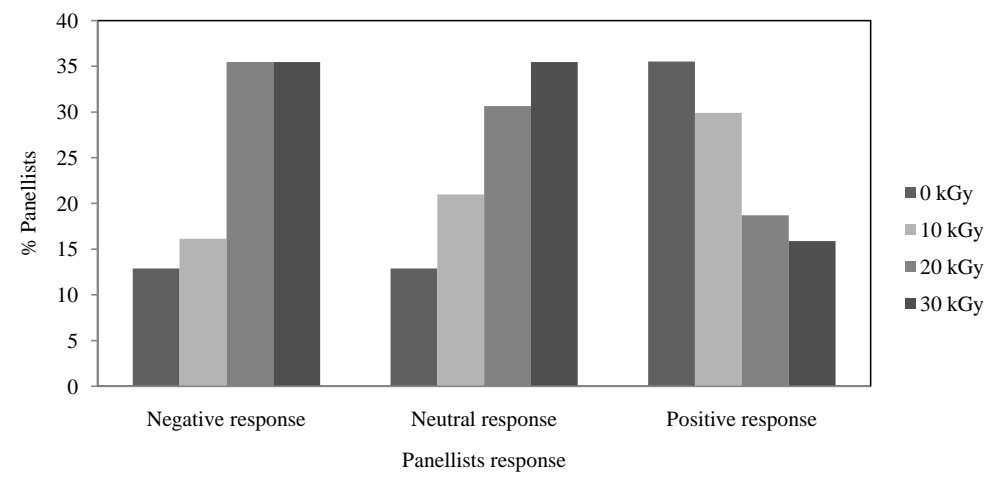

Figure 2. Percentage of positive, neutral and negative responses for the appearance of the sorghum porridge component of the RTE meal irradiated at different doses. Negative response (Dislike extremely to dislike moderately); Neutral response (Dislike slightly to like slightly); Positive response (Like moderate to like extremely).

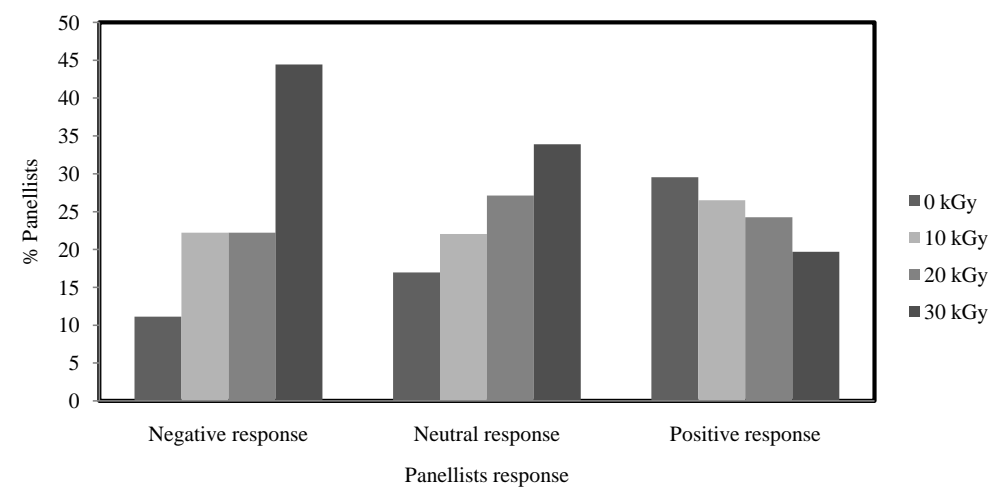

Figure 3. Percentage of positive, neutral and negative responses for appearance of the spinach component of the RTE meal irradiated at different doses. Negative response (Dislike extremely to dislike moderately); Neutral response (Dislike slightly to like slightly); Positive response (Like moderate to like extremely). 
Table 1. Effect of different irradiation doses on the sensory characteristics ${ }^{3}$ of the RTE spinach relish and sorghum porridge meal.

\begin{tabular}{|c|c|c|c|c|c|c|c|}
\hline $\begin{array}{l}\text { Treatments } \\
\text { (kGy) }\end{array}$ & $\begin{array}{l}\text { Appearance }^{1} \\
\text { Porridge }\end{array}$ & $\begin{array}{l}\text { Appearance }^{1} \\
\text { Spinach }\end{array}$ & $\begin{array}{l}\text { Texture }^{1} \\
\text { Porridge }\end{array}$ & $\begin{array}{l}\text { Texture }^{1} \\
\text { Spinach }\end{array}$ & $\begin{array}{l}\text { Taste }^{1} \\
\text { Porridge }\end{array}$ & $\begin{array}{c}\text { Taste }^{1} \\
\text { Spinach }\end{array}$ & $\begin{array}{l}\text { Overall }^{1} \text { acceptability } \\
\text { of meal }\end{array}$ \\
\hline 0 & $\begin{array}{c}7.26^{c} \\
( \pm 1.93)^{2}\end{array}$ & $\begin{array}{c}7.20^{\mathrm{bc}} \\
( \pm 1.62)\end{array}$ & $\begin{array}{c}7.16^{\mathrm{c}} \\
( \pm 1.99)\end{array}$ & $\begin{array}{c}7.12^{\mathrm{b}} \\
( \pm 1.59)\end{array}$ & $\begin{array}{c}6.76^{c} \\
( \pm 2.38)\end{array}$ & $\begin{array}{c}7.28^{\mathrm{b}} \\
( \pm 1.70)\end{array}$ & $\begin{array}{c}7.20^{\mathrm{c}} \\
( \pm 1.35)\end{array}$ \\
\hline 10 & $\begin{array}{c}6.36^{\mathrm{b}} \\
( \pm 1.95)\end{array}$ & $\begin{array}{c}6.74^{\mathrm{ab}} \\
( \pm 1.72)\end{array}$ & $\begin{array}{c}6.16^{\mathrm{b}} \\
( \pm 2.16)\end{array}$ & $\begin{array}{c}7.12^{\mathrm{b}} \\
( \pm 1.59)\end{array}$ & $\begin{array}{c}5.70^{\mathrm{b}} \\
( \pm 2.44)\end{array}$ & $\begin{array}{c}7.08^{\mathrm{b}} \\
( \pm 1.78)\end{array}$ & $\begin{array}{c}6.43^{\mathrm{b}} \\
( \pm 1.80)\end{array}$ \\
\hline 20 & $\begin{array}{c}5.50^{\mathrm{a}} \\
( \pm 2.17)\end{array}$ & $\begin{array}{c}6.58^{\mathrm{ab}} \\
( \pm 1.68)\end{array}$ & $\begin{array}{c}5.64^{\mathrm{b}} \\
( \pm 2.24)\end{array}$ & $\begin{array}{c}6.80^{\mathrm{ab}} \\
( \pm 1.50)\end{array}$ & $\begin{array}{c}4.68^{\mathrm{a}} \\
( \pm 2.21)\end{array}$ & $\begin{array}{c}6.56^{\mathrm{ab}} \\
( \pm 1.94)\end{array}$ & $\begin{array}{c}5.96^{\mathrm{ab}} \\
( \pm 1.70)\end{array}$ \\
\hline 30 & $\begin{array}{c}5.30^{\mathrm{a}} \\
( \pm 2.20)\end{array}$ & $\begin{array}{c}6.30^{\mathrm{a}} \\
( \pm 1.83)\end{array}$ & $\begin{array}{c}4.64^{\mathrm{a}} \\
( \pm 2.63)\end{array}$ & $\begin{array}{c}6.30^{\mathrm{a}} \\
( \pm 2.21)\end{array}$ & $\begin{array}{c}3.82^{\mathrm{a}} \\
( \pm 2.11)\end{array}$ & $\begin{array}{c}6.10^{\mathrm{a}} \\
( \pm 2.13)\end{array}$ & $\begin{array}{c}5.41^{\mathrm{a}} \\
( \pm 1.91)\end{array}$ \\
\hline
\end{tabular}

${ }^{1}$ Mean values in the same column with different letters differ significantly from each other $(\mathrm{p}<0.05) .{ }^{2}$ Standard deviation is given in brackets. ${ }^{3}$ Mean values of the sensory attributes: 1 = Dislike extremely; 9 = Like extremely.

Table 2. Summary of the panellists comments on the appearance, texture, taste of the Sorghum porridge meal.

\begin{tabular}{|c|c|c|c|}
\hline Sample & Appearance & Texture & Taste \\
\hline 0 kGy & $\begin{array}{c}\text { Very light } \\
\text { Much attractive } \\
\text { Excellent }\end{array}$ & $\begin{array}{c}\text { Best } \\
\text { Nice and firm } \\
\text { Excellent }\end{array}$ & $\begin{array}{l}\text { Very nice } \\
\text { Delicious }\end{array}$ \\
\hline 10 kGy & $\begin{array}{l}\text { Not very bad } \\
\text { Nice than the rest }\end{array}$ & $\begin{array}{c}\text { Granules bit too fine } \\
\text { Bit firm } \\
\text { Good quality } \\
\text { Bit soft }\end{array}$ & $\begin{array}{l}\text { Well cooked } \\
\text { Tasty }\end{array}$ \\
\hline 20 kGy & $\begin{array}{c}\text { Watery } \\
\text { Colour is acceptable } \\
\text { Appearance is acceptable } \\
\text { Bit watery } \\
\text { Too white }\end{array}$ & $\begin{array}{c}\text { Too soft } \\
\text { Not firm } \\
\text { Texture not right } \\
\text { Slightly soft texture }\end{array}$ & $\begin{array}{l}\text { Taste not good } \\
\text { Undercooked } \\
\text { Bit sweet } \\
\text { Sour }\end{array}$ \\
\hline 30 kGy & $\begin{array}{l}\text { Too watery } \\
\text { Looks overcooked } \\
\text { Too whitish }\end{array}$ & $\begin{array}{c}\text { Too soft } \\
\text { Soft and nice texture } \\
\text { Need to be improved } \\
\text { Not firm } \\
\text { Bad texture }\end{array}$ & $\begin{array}{c}\text { Did not taste like sorghum porridge } \\
\text { Did not taste nice } \\
\text { Moderate } \\
\text { Taste spoiled } \\
\text { Sweet }\end{array}$ \\
\hline
\end{tabular}

Table 3. Summary of the panellists comments on the appearance, texture, taste of the spinach relish and the overall acceptability of the meal.

\begin{tabular}{|c|c|c|c|c|}
\hline Sample & Appearance & Texture & Taste & Overall acceptability of the meal \\
\hline $0 \mathrm{kGy}$ & Excellent & Excellent & $\begin{array}{c}\text { Taste good } \\
\text { Less spiced }\end{array}$ & $\begin{array}{c}\text { Extremely likable } \\
\text { Best meal } \\
\text { Pleasant }\end{array}$ \\
\hline 10 kGy & $\begin{array}{l}\text { Looks okay } \\
\text { Not bad }\end{array}$ & $\begin{array}{c}\text { Fine } \\
\text { Soft } \\
\text { Soft but nice }\end{array}$ & $\begin{array}{c}\text { Very good } \\
\text { Well cooked }\end{array}$ & $\begin{array}{c}\text { Very good } \\
\text { Delicious than the rest }\end{array}$ \\
\hline 20 kGy & $\begin{array}{c}\text { Acceptable colour } \\
\text { Acceptable appearance }\end{array}$ & $\begin{array}{l}\text { Texture not right } \\
\text { Soft and nice }\end{array}$ & $\begin{array}{c}\text { Good } \\
\text { Taste not good }\end{array}$ & Not as good as sample A and B \\
\hline 30 kGy & Looks watery & $\begin{array}{c}\text { Need to be improved } \\
\text { Good texture }\end{array}$ & $\begin{array}{l}\text { Did not taste nice } \\
\text { Good eating quality }\end{array}$ & $\begin{array}{c}\text { Appearance not appetizing } \\
\text { Meal too watery } \\
\text { Poor taste }\end{array}$ \\
\hline
\end{tabular}




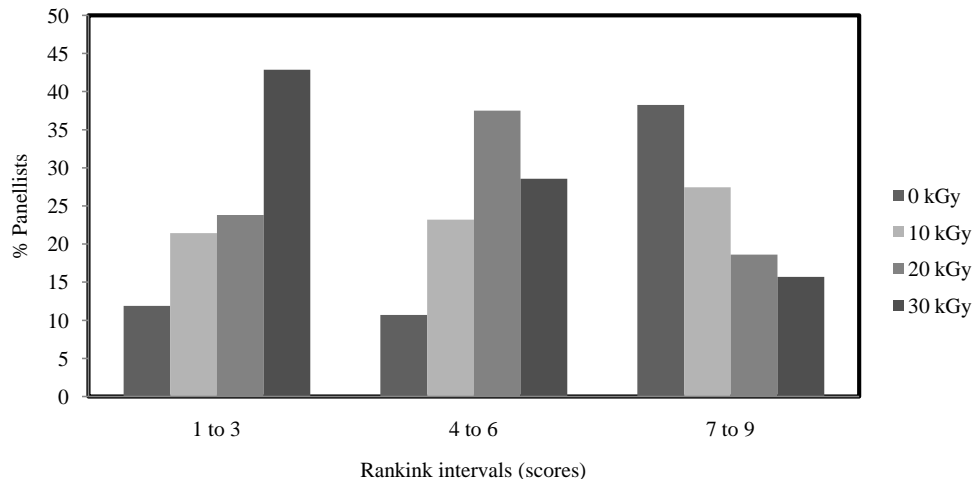

Figure 4. Percentage of positive, neutral and negative responses for the texture of the sorghum porridge component of the RTE meal irradiated at different doses. 1 - 3: Negative response (Dislike extremely to dislike moderately); 4 - 6: Neutral response (Dislike slightly to like slightly); 7 - 9: Positive response (Like moderately to like extremely).

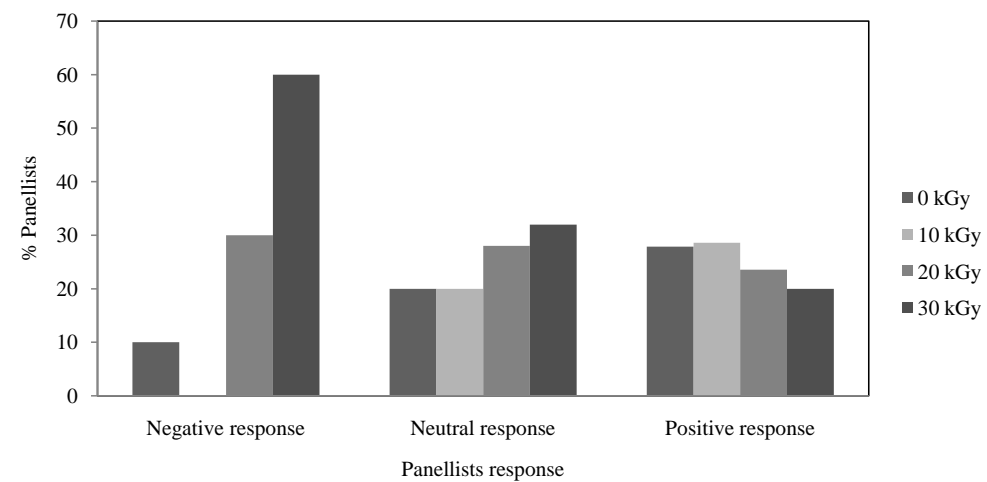

Figure 5. Percentage of positive, neutral and negative responses for the texture of the spinach relish of the RTE meal irradiated at different doses. Negative response (Dislike extremely to dislike moderately); Neutral response (Dislike slightly to like slightly); Positive response (Like moderately to like extremely).

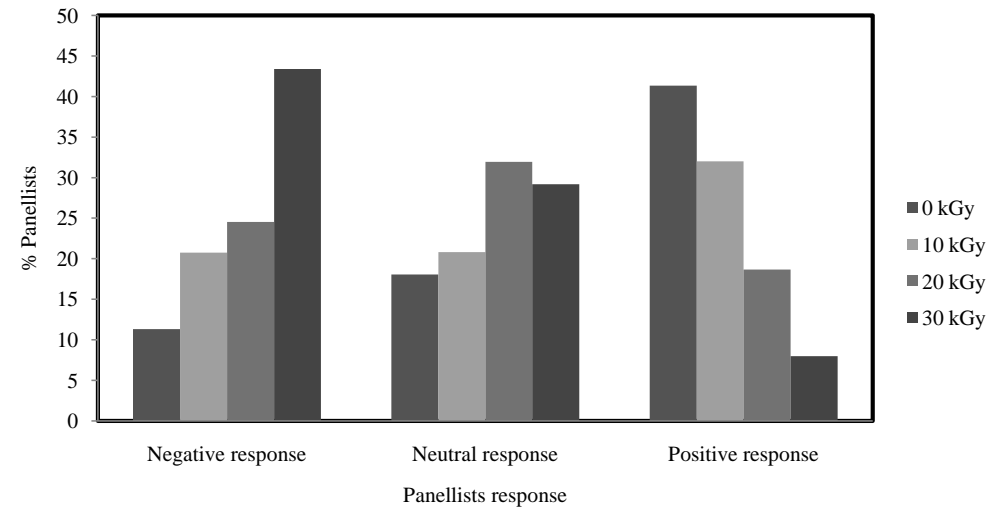

Figure 6. Percentage of positive, neutral and negative responses for the taste of the sorghum porridge component of the RTE meal irradiated at different doses. Negative response (Dislike extremely to dislike moderately); Neutral response (Dislike slightly to like slightly); Positive response (Like moderately to like extremely). 


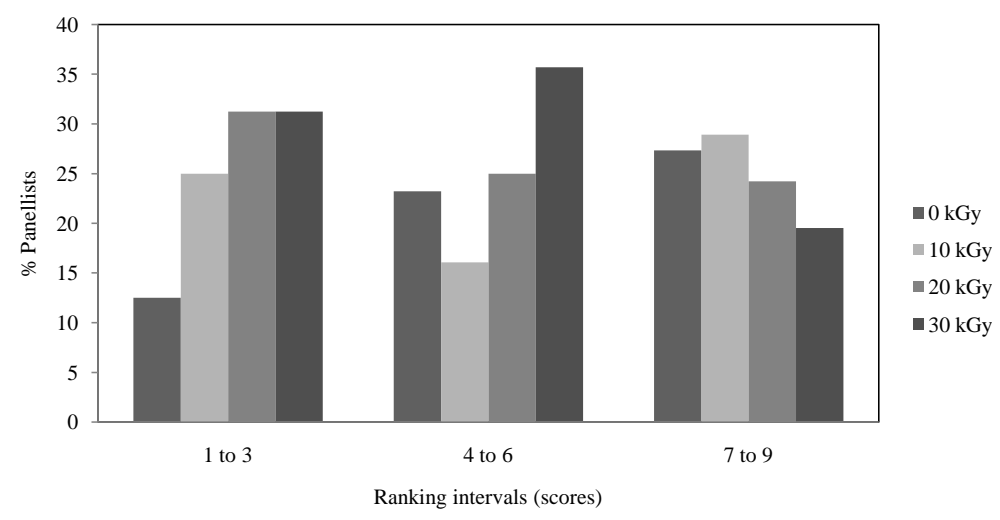

Figure 7. Percentage of positive, neutral and negative responses for the taste of the spinach relish component of the RTE meal irradiated at different doses. 1 - 3: Negative response (Dislike extremely to dislike moderately); 4 - 6: Neutral response (Dislike slightly to like slightly); 7 - 9: Positive response (Like moderately to like extremely).

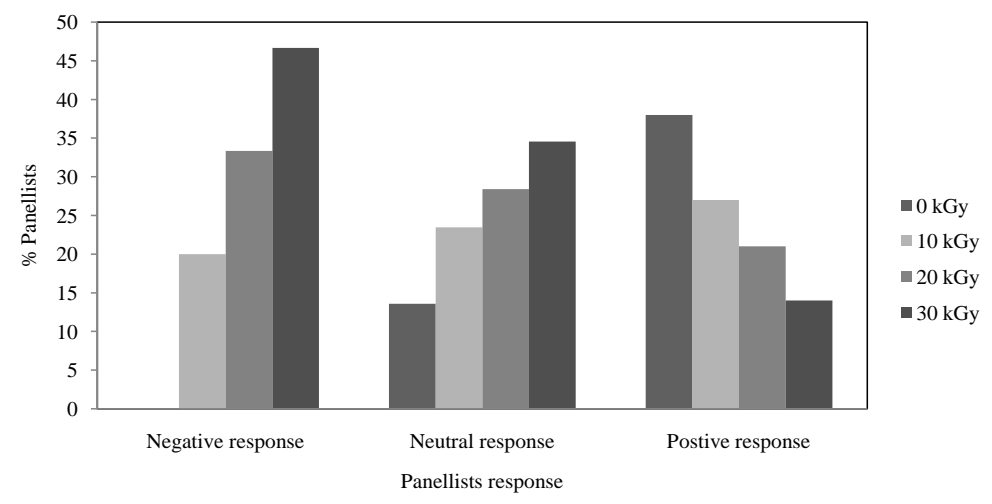

Figure 8. Percentage of positive, neutral and negative responses for the overall acceptability of the RTE meal irradiated at different doses. Negative response (Dislike extremely to dislike moderately); Neutral response (Dislike slightly to like slightly); Positive response (Like moderately to like extremely).

between the appearance, texture and taste of samples irradiated at 0,10 and $20 \mathrm{kGy}$ (Table 1). In all attributes the sample irradiated at $30 \mathrm{kGy}$ was significantly less liked than the control sample. However, there were no significant differences $(\mathrm{p}<0.05)$ in the appearance, texture and taste between spinach samples irradiated at 20 and $30 \mathrm{kGy}$. The distribution of panellists for liking the four samples irradiated at different irradiation doses showed that a lower percentage of panellists perceived the control sample as negative compared to other samples (Figure 3, Figure 5 and Figure 7). The distribution also showed that in general the percentage of negative response and the neutral response (dislike slightly to like slightly) increased with increased irradiation dose while the percentage of positive response (like moderately to like extremely) decreased with increased irradiation dose. The mean score values decreased with increased irradiation doses.

With the sorghum porridge component a different trend for the appearance, texture and taste was observed (Table 1 and Figure 2, Figure 4 and Figure 6). There was a significant difference $(\mathrm{p}<0.05)$ in the appearance, texture and taste between the control sample and all other samples (Table 1). Significant differences $(\mathrm{p}<0.05)$ also existed in the appearance and taste between samples irradiated at $10 \mathrm{kGy}$ and other samples. However, there was no significant difference $(\mathrm{p}<0.05)$ in the appearance and taste between samples irradiated at 20 and $30 \mathrm{kGy}$. There were no significant differences $(\mathrm{p}<0.05)$ in the texture between samples irradiated at 10 and $20 \mathrm{kGy}$.

The distribution of panellists for liking the four samples irradiated at different irradiation doses showed a similar trend as that observed in spinach (Figure 2, Figure 4 and Figure 6). Percentages of negative and neutral 
responses increased as the irradiation doses increased, while the percentage of positive responses decreased with increased irradiation dose. The mean score values showed an inverse relationship with irradiation; the scores decreased as the irradiation doses increased.

The effects of different irradiation doses on the overall acceptability of the meal are given in Table 1 and Figure 8. There was a significant difference $(p<0.05)$ in the overall acceptability of the meal between the control sample and other samples. No significant differences $(\mathrm{p}<0.05)$ existed in the overall acceptability between samples irradiated at 20 and $30 \mathrm{kGy}$, and the $10 \mathrm{kGy}$ samples did not show a significant difference to the samples irradiated at $20 \mathrm{kGy}$. However, there was a significant difference in the overall acceptability between the samples irradiated at $10 \mathrm{kGy}$ and samples irradiated at 0 and $30 \mathrm{kGy}$. The distribution of panellists for liking the four samples irradiated at different irradiation doses showed a similar trend to that obtained in the two components of the meal (Figure 8).

\subsection{Discussion}

In this study a consumer acceptability test was performed in order to obtain a cut-off point for the irradiation dose that could be used to produce a RTE spinach relish and sorghum porridge meal. Although the consumer overall acceptability test results showed that the RTE samples irradiated at $10 \mathrm{kGy}$ was not as acceptable as the control sample, the two components of the meal remained acceptable up to a dose of $10 \mathrm{kGy}$. However, the limiting factor for using higher doses above $10 \mathrm{kGy}$ was the porridge component. The tasting scores for samples irradiated at 20 and $30 \mathrm{kGy}$ were lower (less acceptable) than the control and $10 \mathrm{kGy}$ samples in all attributes. This was attributed to the fact that there was a decrease in the sensory acceptability perceived by panellists in samples with increased irradiation dose. The decrease in the overall acceptability of the ready-to-eat meal perceived by the panelists was attributed to the loss in product appearance, texture and taste with increased irradiation dose.

The loss in appearance observed by the participants in the two components of the meal could be due to the oxidation, which might have occurred during the irradiation process. During irradiation in the presence of oxygen highly oxidising free radicals may be formed [9] and this may oxidise the product which might result in the discoloration of the meal components, thereby affecting the product appearance. Spinach component is more likely to lose the appearance due to oxidation as chlorophyll available in the spinach is expected to be more sensitive to oxidation while some lipids present in the sorghum porridge component may probably be oxidized during the process. The loss of appearance in the spinach components could have also happened due to the reduced chlorophyll levels during irradiation. According to Myung-Woo et al. [10], the complete destruction of chlorophyll may occur when irradiated at $25 \mathrm{kGy}$. The loss of chlorophyll may therefore result to the discoloration of the spinach component of the meal. On the other hand, a different study by Swallow found out that there is also a change in the water holding capacity (WHC) when food is irradiated [11]. This kind of change could have affected the appearance of the samples irradiated at 20 and $30 \mathrm{kGy}$. Some of the panellists reported the sorghum porridge component irradiated at 20 and $30 \mathrm{kGy}$ to be watery. However, the watery effect could not have been noticed in the spinach component because the meal contained water. As a result the loss of appearance of the spinach component could have been due to leaching as chlorophyll in not soluble in water. Similarly, a different study has suggested that the boiling cooking process significantly reduces the amount of chlorophyll as compared to other cooking methods like steaming [12]. The boiling cooking process used on the preparation of the spinach could have added on the loss of appearance component of the meal.

The textural changes of the two components of the meal with increased irradiation doses reduced the overall acceptability of the RTE meal irradiated at 20 and $30 \mathrm{kGy}$. Samples irradiated at $30 \mathrm{kGy}$ were perceived to be softer than those irradiated at lower doses. The softer texture of the porridge samples after irradiation was due to the fact that irradiation results in the breakdown of complex carbohydrate molecules into simpler compounds such as dextrin, glucose, maltose and other radiolytic products [13]. This tendency of causing depolymerisation of the starch molecules could be the cause of softness of porridge perceived by panelists at high irradiation dose levels.

The change in texture that was observed in the spinach component with increased irradiation dose was expected although the scores recorded by panelists were still at acceptable levels for all samples. The textural loss could be due to the fact that softening of plant material usually occurs during heat treatment and irradiation processing. Heat processing damages or destroys membranes and disrupts intercellular structures, resulting in 
cell separations [15]. In addition, during irradiation processing there is a partial degradation of pectins and cellulose, which weakens the structural tissue resulting in softening or loss of texture [14] [15]. The change in texture due to irradiation is usually $\mathrm{pH}$ dependent [16].

The fact that the spinach component was perceived to be more liked than the porridge component after irradiation could be due the fact that vegetables tend to lose their texture during the cooking processes. This could be the reason for the failure of the participants to detect the textural changes after irradiation in the spinach component.

Regarding the taste of the two components of the meal, irradiation had less effect on the taste of the spinach than on the sorghum porridge. The possible explanation for this could be due to undesirable changes that occur in certain foods, which may be caused directly by irradiation or indirectly as a result of post irradiation reactions [17]. Water undergoes radiolysis when irradiated and in addition, free radicals are formed and react with each other as diffusion occurs. Some of the products formed along the track escape and then react with solute molecules. In presence of oxygen the oxidation is accelerated [9] and the formation of off-flavours and off-odours are promoted due to formation of peroxides during the oxidation process [14].

Also, proteins and other nitrogenous compounds are the most sensitive to irradiation effects in foods with regard to off flavour development. The products of irradiation that have been reported are $\mathrm{NH}_{3}$, hydrogen, $\mathrm{CO}_{2}$, $\mathrm{H}_{2} \mathrm{~S}$, amides and carbonyls. Apart from other factors, the formation of these products depends on the irradiation dose, temperature, amount of oxygen and amount of moisture present. These products could influence the formation of off-flavours and off-odours.

The fact that sorghum porridge has more amino acids and peptides than spinach could be the reason for the differences in the loss of the taste of the two meal components. In addition, the depolymerisation of starch molecules that occurs in porridge could affect the taste of the porridge due to formation of glucose, maltose, and radiolytic products [9] [13]. Formation of these sugars increases the sweetness of the porridge, which is not the typical taste of the sorghum porridge. Sweetness of the sorghum porridge component of the meal was reported by panelists and this could have resulted in the low acceptability of the samples irradiated at higher doses.

\section{Conclusion}

The application of a $10 \mathrm{kGy}$ target irradiation dose was shown to produce a RTE spinach relish and sorghum porridge meal of acceptable consumer sensory qualities. Irradiating at higher doses affected the sensory acceptability of the meal components, especially the sorghum porridge component of the meal.

\section{Acknowledgements}

Funding from the International Atomic Energy Agency (IAEA) and the support from Prof. A. Minnaar of the Department of Food Science at the University of Pretoria are greatly acknowledged and appreciated.

\section{Competing Interests}

The author has declared that no competing interests exist.

\section{References}

[1] Dendy, D.A.V. (1995) Sorghum and Millets: Production and Importance. In: Dendy, D.A.V., Ed., Sorghum and Millets: Chemistry and Technology, American Association of Cereal Chemists, St. Paul, 11-26.

[2] Taylor, J.R.N., Dewar, J., Taylor, J. and Von Ascheraden, R.F. (1997) Factors Affecting the Porridge-Making Quality of South African Sorghums. Journal of Science of Food and Agriculture, 73, 464-470. http://dx.doi.org/10.1002/(SICI)1097-0010(199704)73:4<464::AID-JSFA751>3.0.CO;2-L

[3] Van Eeden, T.S. and Gericke, G.J. (1996) Effect of Acculturation on Habitual Food Intake and Dietary Patterns of Rural Urban Black Home Economics Students. South African Journal of Food Science and Nutrition, 8, 85-94.

[4] Duodu, K.G., Minnaar, A. and Taylor, J.R.N. (1999) Effect of Cooking and Irradiation on the Labile Vitamins and Antinutrient Content of a Traditional African Sorghum Porridge and Spinach Relish. Food Chemistry, 66, 21-27. http://dx.doi.org/10.1016/S0308-8146(98)00070-3

[5] Obilana, A.O. (1998) Modified Atmosphere Packaging and Irradiation Preservation of Sorghum Porridge and Spinach Relish Meal. M.Sc. (Agric) Dissertation, University of Pretoria, Pretoria. 
[6] Banwart, G.J. (1989) Basic Food Microbiology. 2nd Edition, Van Nostrand Reinhold, New York.

[7] Andrews, L.S., Ahmedna, M., Grodner, R.M., Liuzzo, J.A. Murano, E.A., Rao, R.M., Shane, S. and Wilson, P.W. (1998) Food Preservation Using Ionizing Radiation. Reviews of Environmental Contamination and Toxicology, 154, 1-53. http://dx.doi.org/10.1007/978-1-4612-2208-8_1

[8] O’Bryan, C.A., Crandall, P.G., Ricke, S.C. and Olson, D.G. (2008) Impact of Irradiation on the Safety and Quality of Poultry and Meat Products: A Review. Crtical Review in Food Science and Nutrition, 48, 442-457. http://dx.doi.org/10.1080/10408390701425698

[9] Thakur, B.R. and Singh, R.K. (1994) Food Irradiation-Chemistry and Applications. Food Review International, 10, 437-473. http://dx.doi.org/10.1080/87559129409541012

[10] Myung-Woo, B., Cheorun, J., Kyong-Haeng, L. and Kyung-Su, K. (2002) Chlorophyll Breakdown by Gamma Irradiation in a Model System Containing Linoleic Acid. Journal of the American Oil Chemists' Society, 79, 145-150. http://dx.doi.org/10.1007/s11746-002-0449-y

[11] Swallow, A.J. (1991) Effect of Irradiation of Protein. In: Hudson, B.J.F., Ed., Development in Food Proteins 7, Elsevier Applied Science, London, 195-229.

[12] Yuan, G., Sun, B., Yuan, J. and Wand, Q. (2009) Effect of Different Cooking Methods on Health-Promoting Compounds of Broccoli. Journal of Zhejiang University Science B, 10, 580-588. http://dx.doi.org/10.1631/jzus.B0920051

[13] Diehl, J.F. (1990) Safety of Irradiated Foods. Marcel Dekker, Inc., New York, 59.

[14] Urbain, W.M. (1986) Food Irradiation. Academic Press, New York, 170-216. http://dx.doi.org/10.1016/B978-0-12-709370-3.50014-2

[15] Ley, F.J. (1983) New Interest in Use of Irradiation in the Food Industry. In: Roberts, T.A. and Skinner, T.A., Eds., Food Microbiology: Advances and Prospects, Academic Press, London, 113-129.

[16] Bao, J. and Corke, H. (2002) Pasting Properties of y-Irradiated Rice Starches as Affected by pH. Journal of Agriculture and Food Chemistry, 50, 336-341. http://dx.doi.org/10.1021/jf010230c

[17] Jay, J.M. (1998) Modern Food Microbiology. 5th Edition, Aspen Publishers, Inc., Gaithersburg. 
Scientific Research Publishing (SCIRP) is one of the largest Open Access journal publishers. It is currently publishing more than 200 open access, online, peer-reviewed journals covering a wide range of academic disciplines. SCIRP serves the worldwide academic communities and contributes to the progress and application of science with its publication.

Other selected journals from SCIRP are listed as below. Submit your manuscript to us via either submit@scirp.org or Online Submission Portal.
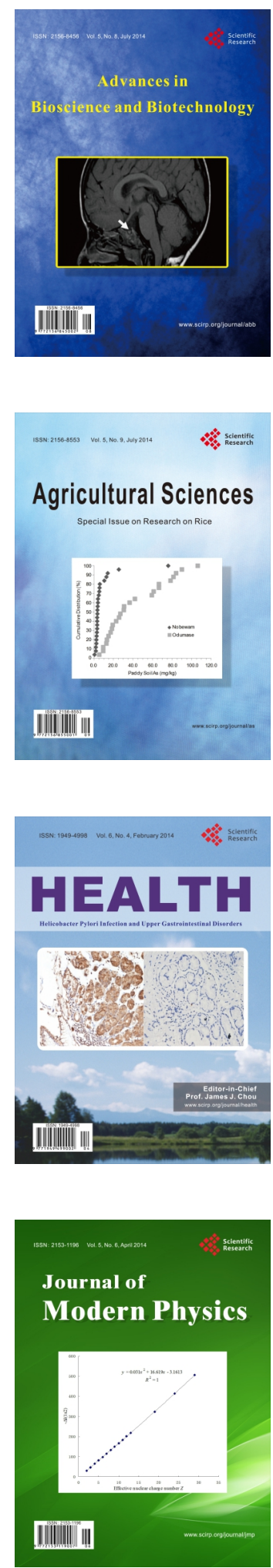
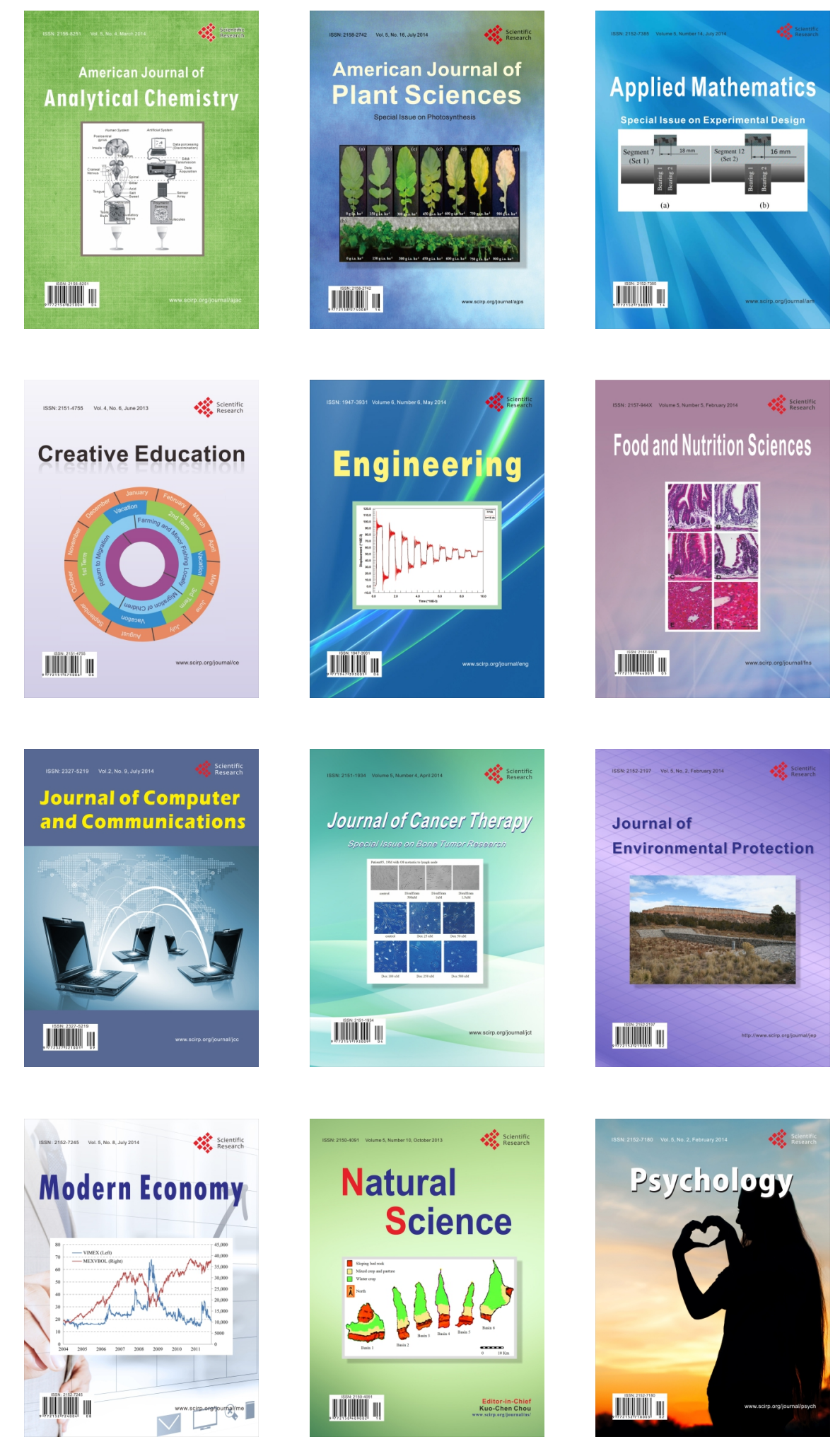